\title{
Congenital abnormalities and arthrogryposis in newly born lambs in Al Muthanna province Iraq. Suspicion of Akabane virus infection
}

\author{
Anormalidades congênitas e artrogripose em cordeiros recém-nascidos \\ na província de Al Muthanna, Iraque. Suspeita de \\ infecção pelo vírus Akabane
}

\author{
Karima Akool Al-Salihi ${ }^{1}$ (D); Ahmed Hameed Al-Dabhawi ${ }^{2}$
}

\begin{abstract}
${ }^{1}$ Al Muthanna University, College of Veterinary Medicine, Department of Veterinary Internal Medicine, Sammawah, Iraq ${ }^{2}$ University of Kufa, Faculty of Veterinary Medicine, Department of Veterinary Pathololgy, Najaf, Iraq
\end{abstract}

\begin{abstract}
Akabane virus, a member of the Orthobunyavirus genus in the family Bunyaviridae, causes congenital abnormalities and arthrogryposis with hydrocephalus or hydroencephaly in ruminants. This study intends to describe the clinical signs, gross and histopathological features seen in 25 affected lambs in an outbreak of congenital arthrogryposis with hydrocephalus or hydranencephaly in Al-Muthanna governorate, Iraq after a large number of stillbirths and musculoskeletal deformities from October 2017 to May 2018. Skeletal muscle hypoplasia was seen in the limbs of the affected lambs accompanied with severe arthrogryposis and gross visible brain malformations. In addition, fetal mummifications, stillbirths, and dead lambs were also seen. The most histopathological features in muscle fibers were degenerative lesions and absences of cross-striation accompanied with mild infiltration of neutrophils and mononuclear cells in severely affected lambs. The meninges of affected lambs revealed fused membranes with focal areas of fibrous thickenings and necrotic debris. In conclusion, according to clinical signs, gross and histopathological investigations, Akabane virus, a member of the Orthobunyavirus genus in the family Bunyaviridae, causes congenital abnormalities and arthrogryposis with hydrocephalus or hydroencephaly in ruminants and could be the cause of this outbreak, although future studies must be performed to confirm the etiology of this outbreak. Moreover, other causes of hydrocephalus or cerebellar malformation, such as Schmallenberg virus, bluetongue virus and border disease virus and teratogenic plants that lead to arthrogryposis, have to be investigated. Also, the authorities should take prevention and control measurements to stop the replication of arthropod vectors.
\end{abstract}

Keywords: Akabane virus. Arthrogryposis. Bunyavirus. Degenerative lesions. Iraq.

\section{RESUMO}

O presente trabalho descreve os sinais clínicos, as lesões macroscópicas e os aspectos histológicos observados em 25 cordeiros acometidos em um surto de artrogripose congênita com hidrocéfalo ou hidrocefalia registrado no Iraque, governadoria Al-Muthama após a ocorrência de nascimentos prematuros e deformidades músculo-esqueléticas no período compreendido entre outubro de 2017 e maio de 2018. A hipoplasia músculo-esquelética foi observada nos membros dos cordeiros afetados, acompanhada de severa artrogripose e malformações cerebrais, grosseiras visíveis, além de mumificações fetais, nascimentos prematuros e morte de cordeiros. Os principais aspectos histopatológicos nas fibras musculares foram lesões degenerativas e ausências da estriação cruzada acompanhada de leve infiltração de neutrófilos e células mononucleares dos cordeiros severamente afetados. As meninges dos cordeiros afetados apresentaram fusão de membranas com áreas focais de espessamento fibroso e debris necróticos. O vírus Akabane, um membro do gênero Orthobunyavirus, da família Bunyaviridae, causa anormalidades congênitas e artrogripose com hidrocéfalo e hidrocefalia em ruminantes e poderá vir a ser a causa do presente surto. Os autores recomendam a realização de novos estudos com investigações epidemiológicas e isolamento do agente causal. Contudo, outras causas de hidrocéfalo ou malformações cerebrais como as determinadas pelo vírus Schmallenberg, vírus da língua azul e vírus da doença de border, bem como de plantas teratogênicas que determinam a artrogripose, também deverão ser investigadas. As autoridades sanitárias deverão tomar medidas de prevenção e controle para bloquear a replicação do vírus em artrópodes vetores.

Palavras-chave: Virus Akabane. Artrogripose. Bunyavirus. Lesões degenerativas. Iraque. 
Correspondence to:

Karima Akool Al-Salihi

Al Muthanna University, College of Veterinary Medicine,

Department of Veterinary Internal Medicine

Sammawah City, Al Kashla street, Iraq

e-mail: kama_akool18@yahoo.co.uk

Received: February 17, 2019

Approved: September 12, 2019

How to cite: Al-Salihi KA, Al-Dabhawi AH. Congenital abnormalities and arthrogryposis in newly born lambs in Al Muthanna province Iraq. Suspicion of Akabane virus infection. Braz J Vet Res Anim Sci. 2019;56(3):e154854. https://doi.org/10.11606/issn.1678-4456.bjvras.2019.154854

\section{Introduction}

Abortions, premature births, stillbirths, congenital arthrogryposis with hydrocephalus or hydroencephaly in lambs and calves caused by Akabane disease virus are recorded in Japan (Kono et al., 2008; Oya et al., 1961), Australia (Cybinski et al., 1978), Korea (Bak et al., 1980; Lee et al., 2016) and Israel (Stram et al., 2004).

The Akabane virus is an insect-transmitted virus, and its antibodies are found in many countries in the Middle East (Taylor \& Mellor, 1994), Saudi Arabia (Abu Elzein et al., 1998), Asia (Jun et al., 2012), Africa (Metselaar \& Robin, 1976), The disease is frequent in many tropical and subtropical areas (Liao et al., 1996). Moreover, an outbreak of Akabane disease was also reported in cattle in the Turkish province of Aydin in 1980 using serological indication (Taylor \& Mellor, 1994). Akabane virus is a teratogenic disease, and cattle, sheep and goat fetuses are infected in-utero. However, infection occurs as asymptomatic in horses, buffalo, deer, and pigs and has been demonstrated serologically in endemic areas (Merck Sharp \& Dohme Corp, 2019).

The causative agent, Akabane virus, is an Orthobunyavirus that belongs to the member of the Simbu serogroup of the family Bunyaviridae, and it spreads by biting midges (Culicoides SPP) in Australia (Cybinski et al., 1978), Japan (Oya et al., 1961), and Kenya (Metselaar \& Robin, 1976). Moreover, the favorable environmental circumstances like extended humid summer, vector and causative virus may spread beyond its traditional route into new areas, and occurrences of congenital infection may be predictable. The time of gestation at which virus infection occurs and the strain of virus is affected in the incidence of Akabane disease. The highest incidence is observed after infection in the third and fourth months, when up to $40 \%$ of calves may be born with defects. The disease in sheep and goats is recognized, but it is dissimilar from the consecutive manifestation that occurs in cattle due to the shorter period of gestation and susceptibility. Most abnormalities occur after infection between days 28-56 of gestation. Scarce, if any, anomalies are seen after infection at other times. Nonetheless, it is not identified whether the infection in large or small ruminants very early in gestation results in lethal infection, with the abortion of the fetus (Merck Sharp \& Dohme Corp, 2019). Although adult animals do generally not exhibit clinical signs, if there is an increase in the cases of neurological disease in newborn ruminants in late summer, the akabane infection may be suspected.

Al-Muthanna is one of the Iraqi governorates. It is located 280 kilometers (174 miles) southeast of Baghdad and midway between Baghdad and Basra. Al-Muthanna province area is $51,740 \mathrm{~km}^{2}$ and has a desert climate. Summer temperatures easily exceed $40^{\circ} \mathrm{C}$, while rainfall is limited to the winter months. Sandy desert areas in Al-Muthanna are covered with desert plants and periodic pastures of various concentrations, where most sheep flocks are reared and migrate from one place to another looking for grassland and water oases. The average high temperature reaches $15^{\circ} \mathrm{C}$ (January) to $42^{\circ} \mathrm{C}$ (July), while the average low temperature is reaches $7^{\circ} \mathrm{C}$ (January) to $30^{\circ} \mathrm{C}$ (July) (Al-Salihi et al., 2017). Al-Muthanna province is considered to have the second highest number of small ruminant population in Iraq with a total number of 268,537 (3.5\%) and 42,375 (2.9\%) for sheep and goats, respectively, according to the 2008 livestock census of Veterinary Directorate, Republic of Iraq, Ministry of Agriculture (Veterinary Directorate Livestock, 2008; Al-Salihi, 2012).

Arthrogryposis and noticeable central nervous system malformations associated with the death of newborn lambs rarely are recorded in Al-Muthanna governorate in Iraq. From October 2017 to May 2018, there was a seasonal assembling of the simultaneous birth of a large number of sheep with congenital malformations accompanied by abortions, stillbirths, congenital arthrogryposis with hydrocephalus and hydroencephaly. Consequently this study describes the clinical signs, gross and histopathological features that were seen in 25 affected lambs in an outbreak of congenital arthrogryposis with hydrocephalus or hydranencephaly in Al-Muthanna governorate

\section{Materials and Methods}

This study was approved by animal and ethical research committee (approval ID: AK10, October 2018). The cases of arthrogryposis with hydrocephalus or hydranencephaly in lambs were screened in the records of Veterinary Hospital, 
Al-Muthanna governorate. From October 2017 to May 2018, 25 lambs were born either with the Caesarian section (10 lambs) or fetotomy (15 lambs) with musculoskeletal abnormalities.

Gross pathological changes were described in all lambs such as arthrogrypotic, and visible brain malformations. Moreover, there were fetal mummifications, stillbirths, and dead lambs that occurred at the beginning of the lambing season. After that season, ewes began to lamb again; however, a more significant number of ewes failed to conceive.

The owners mentioned that the animals grazed in their usual annual places, although the investigators were incapable of finding toxic plants or mineral imbalances to deal with this problem. Moreover, there were no facilities for virus isolations from the affected lambs. The serum samples collected from all ewes were negative for rose Bengal test; meanwhile, all these animals were vaccinated against brucellosis.

In Al-Muthanna governorate, the flocks of sheep were kept and pastured in Badia Al-Muthanna with rainfalls and moderate temperature that encourage the multiplication of large numbers of mosquitoes and biting midges, and led to exposure of early gestation ewes. In all cases, examined organs were included: liver, lung, skeletal muscle, cardiac muscle, kidney, adrenal gland, pancreas, small intestine, trachea, and brain. The brain and spinal cord of only three cases were processed for routine histopathological processing. The tissues fixed in 10\% neutral buffered formalin and routinely embedded in paraffin wax, sectioned at 4-5 $\mu \mathrm{m}$, stained with hematoxylin-eosin (H\&E). The histopathological sections were examined by light microscope connected with digital camera for capture image.

\section{Results}

All 25 affected lambs demonstrated a teratogenic disease problem in sheep flocks. The lambs were delivered at term and born dead. In most twin births, the siblings were also affected. Nonetheless, the ewe infrequently delivered both affected and normal lambs. The Figures 1-10 show the 10 affected lamb that were born with the Caesarian section with diverse gross lesions of Akabane virus infection. The mummified fetuses were sometimes born with affected lambs (Figures 3, 9 and 10). Varied mild to severe appendicular and axial skeleton deformities were found in all lambs.

Lamb deformities were headed to dystocia and all ewes had to be supported at partum. Fifteen lambs (10 lambs) were born with the Caesarian section, while 15 lambs were extracted by fetotomy with musculoskeletal abnormalities. Moreover, 10 ewes died.

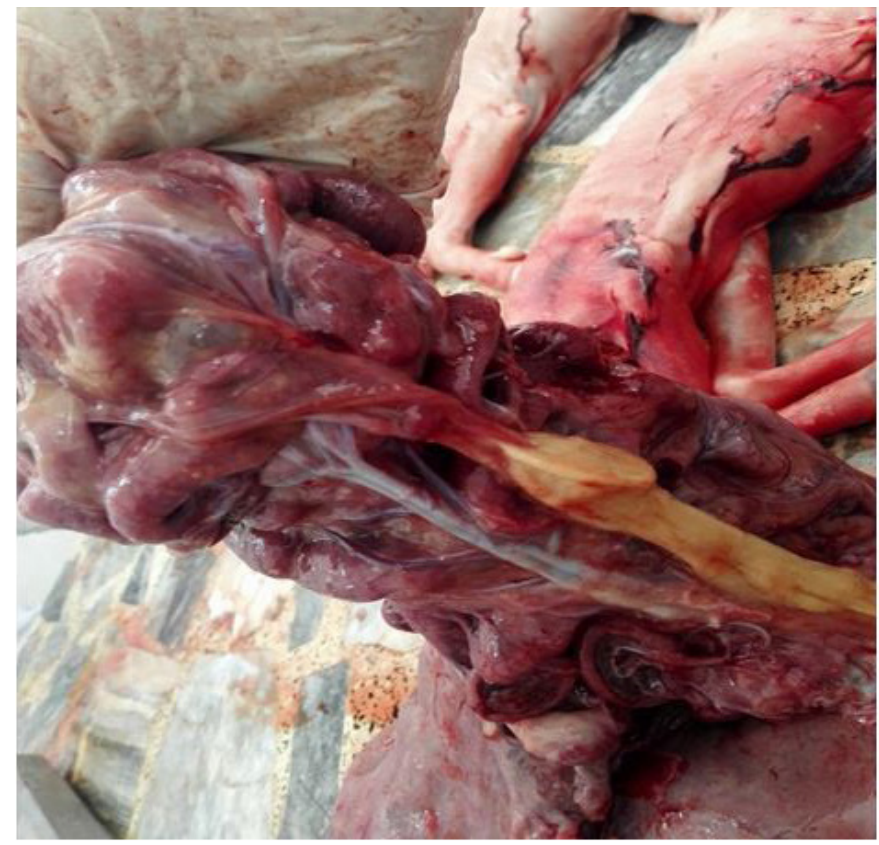

Figure 1. This lamb showed congestion and degeneration of the placenta accompanied with cyst formation attached to the placenta. Joint contracture, ankylosis, and brachygnathia (abnormal shortness of mandible) were also seen.

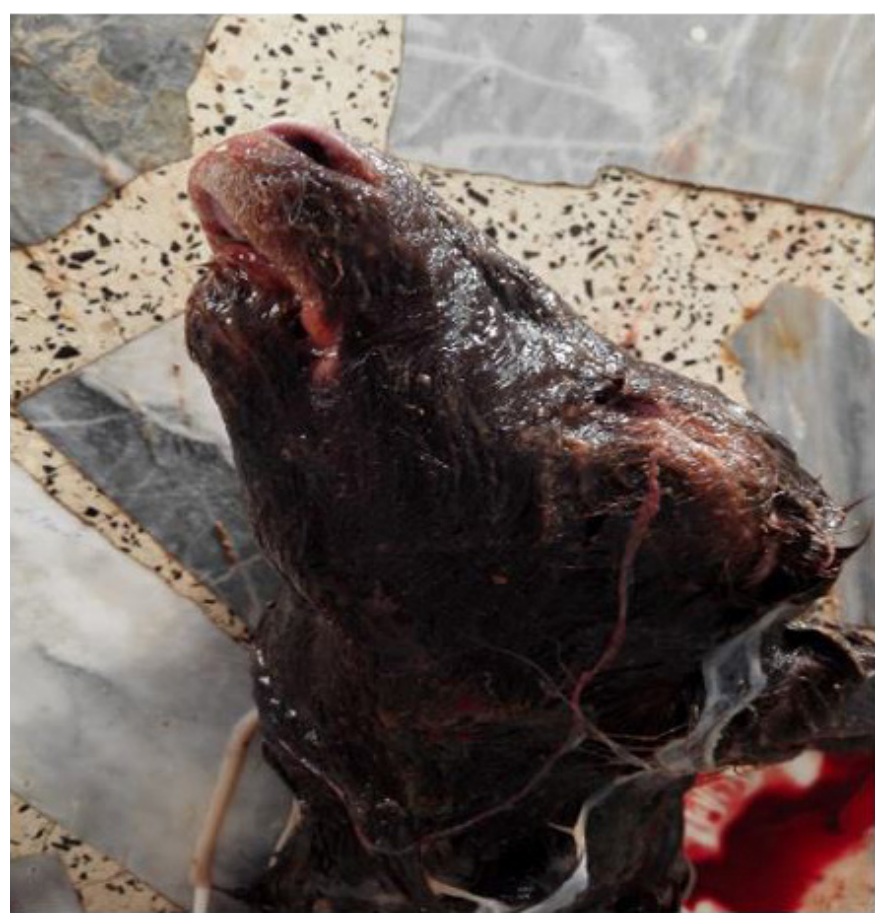

Figure 2. The newly born lamb revealed brachygnathia accompanied with joint contracture and ankylosis.

Most lambs revealed arthrogryposis in all joints, with immobility of multiple joints and fixed flexion (Figures: 1, 2, 4, 5, 6, 7 and 8). Five cases revealed cervicothoracic kyphosis, lordosis, and abnormal head posture. Most lambs revealed reduce pale and firm muscle mass. A high leg-to-body length ratio appeared in lambs. 


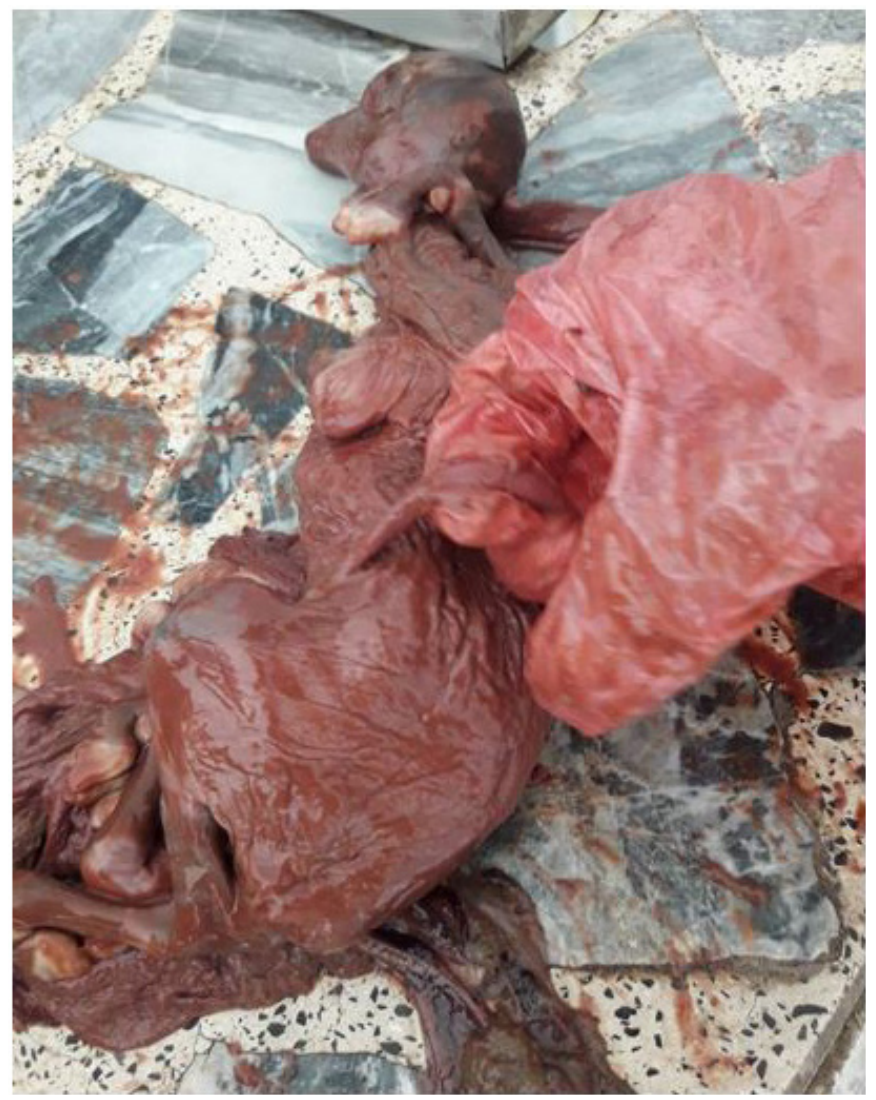

Figure 3. Shows a mummified fetus.

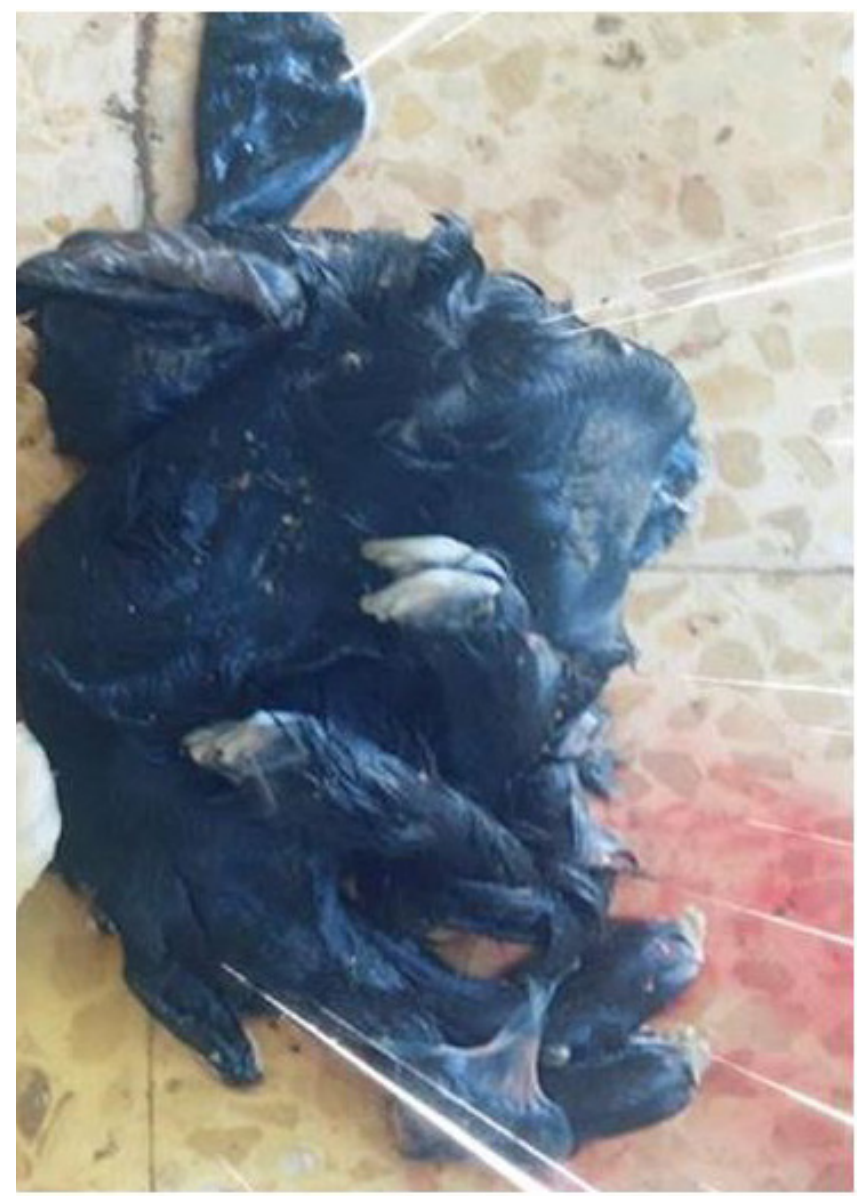

Figure 4. This lamb revealed cervicothoracic kyphosis, cervical lordosis and abnormal head posture accompanied with arthrogryposis and brachygnathia.

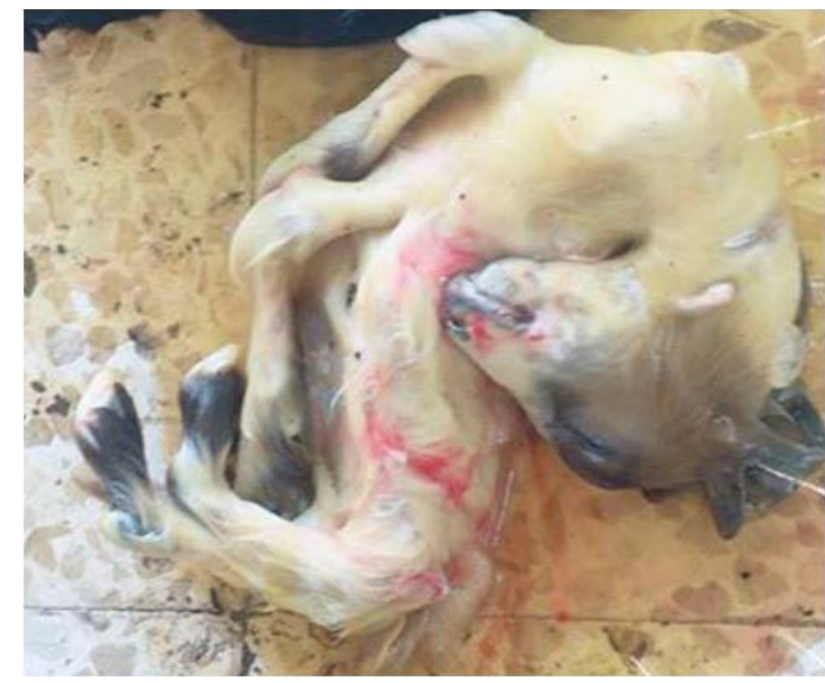

Figure 5. This lamb showed cervicothoracic kyphosis, cervical lordosis and abnormal head posture accompanied with arthrogryposis and brachygnathia.

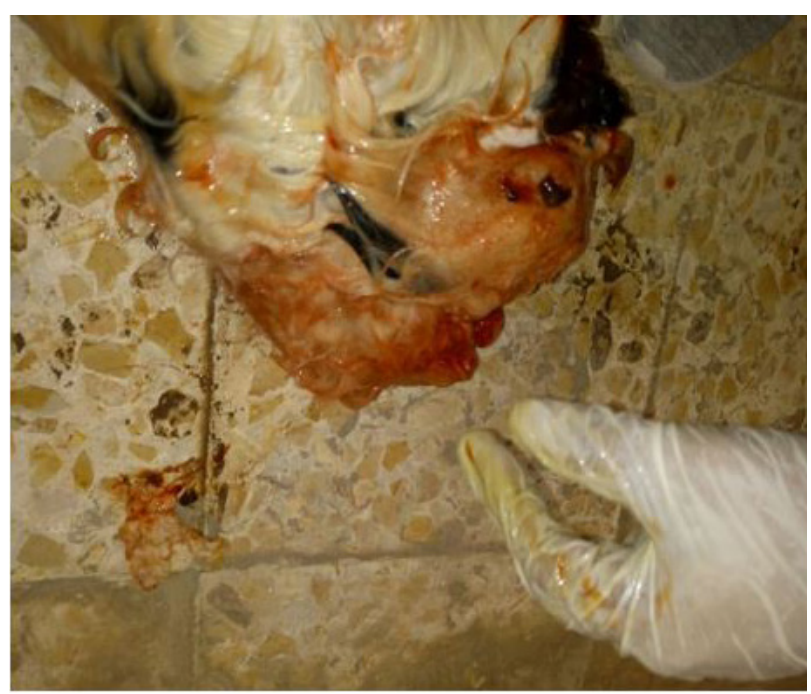

Figure 6. This lamb showed cervicothoracic kyphosis, hydrocephalus, cervical lordosis, and abnormal head posture accompanied with arthrogryposis and brachygnathia.

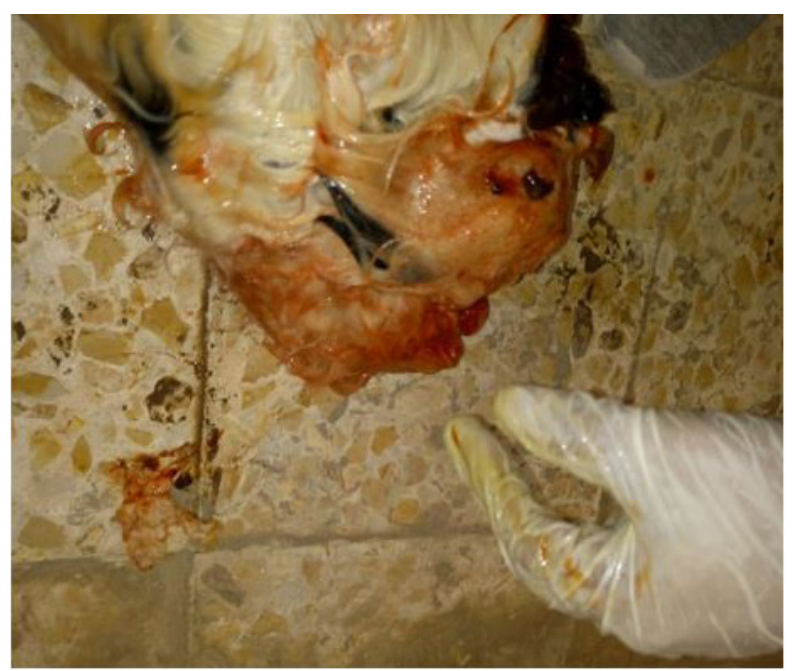

Figure 7. This lamb showed hydrocephalus, cervical lordosis, and abnormal head posture accompanied with arthrogryposis and brachygnathia. 
The affected lambs revealed visible gross lesions in the central nervous system that including the reduction of the brain size (microcephaly) and different degrees of hydrocephalus.

The most histopathological lesions appeared in the nervous system (brain and spinal cord) and muscles. The most common injuries seen in muscle fibers were degenerative lesions accompanied with rounding narrow and short individual cells with few nuclei and absences of cross-striation. The muscle fibers of some cases were separated by adipocytes and loss of alveolar connective

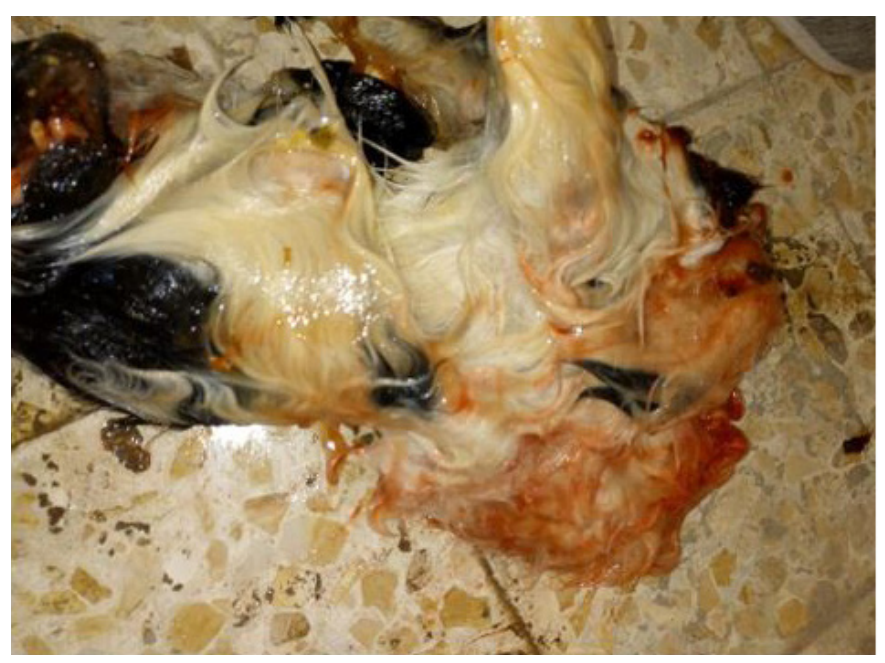

Figure 8. This lamb showed arthrogryposis, brachygnathia, severe cervicothoracic kyphosis, arthrogryposis, and brachygnathia.

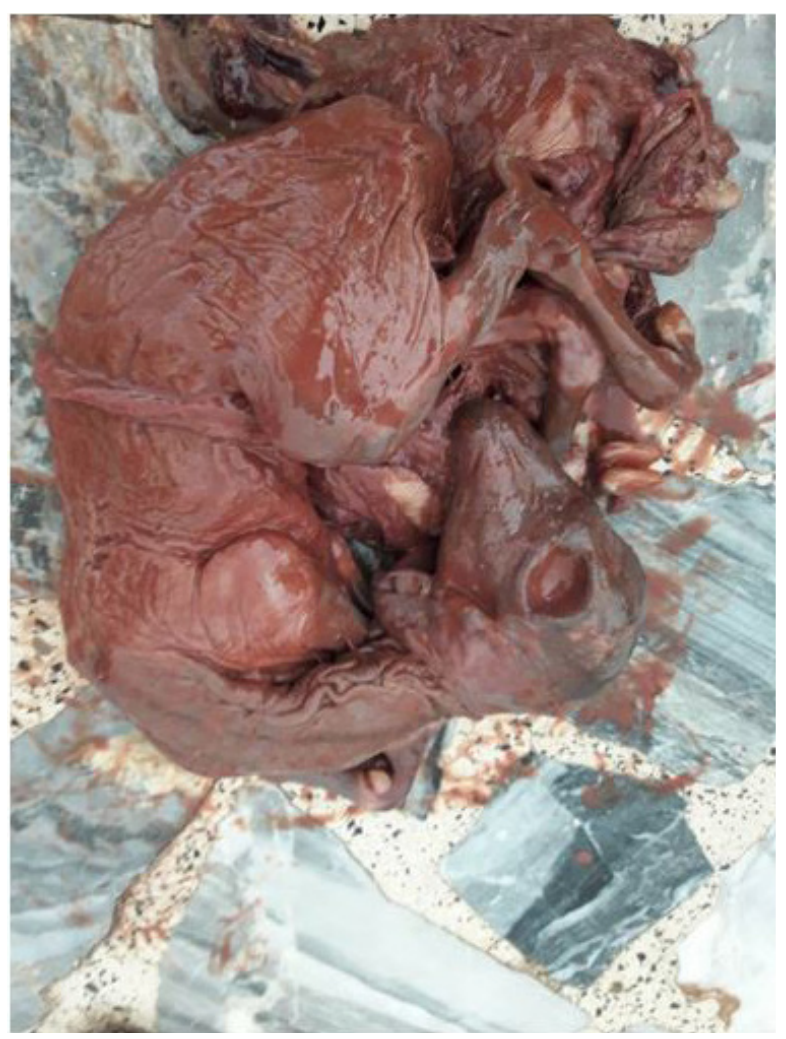

Figures 9. Shows the mummified fetus that delivered by CS Caesarian section. tissue. Moreover, mild infiltration of neutrophils and mononuclear cells were seen in the severely affected lambs (Figure 11). The meninges of lambs with arthrogryposis and hydroencephaly revealed fused membranes accompanied with focal areas of fibrous thickenings and necrotic debris. The spinal cord showed a diminished in size with a marked reduction in the extent of ventral cord myelination accompanied by degenerative lesions and reduction in the ventral horn neurons. Moreover, small mineralized plaques were also seen beneath the meninges of the spinal cord. A marked capillary proliferation, vascular engorgement, and swelling of the vascular endothelium were observed

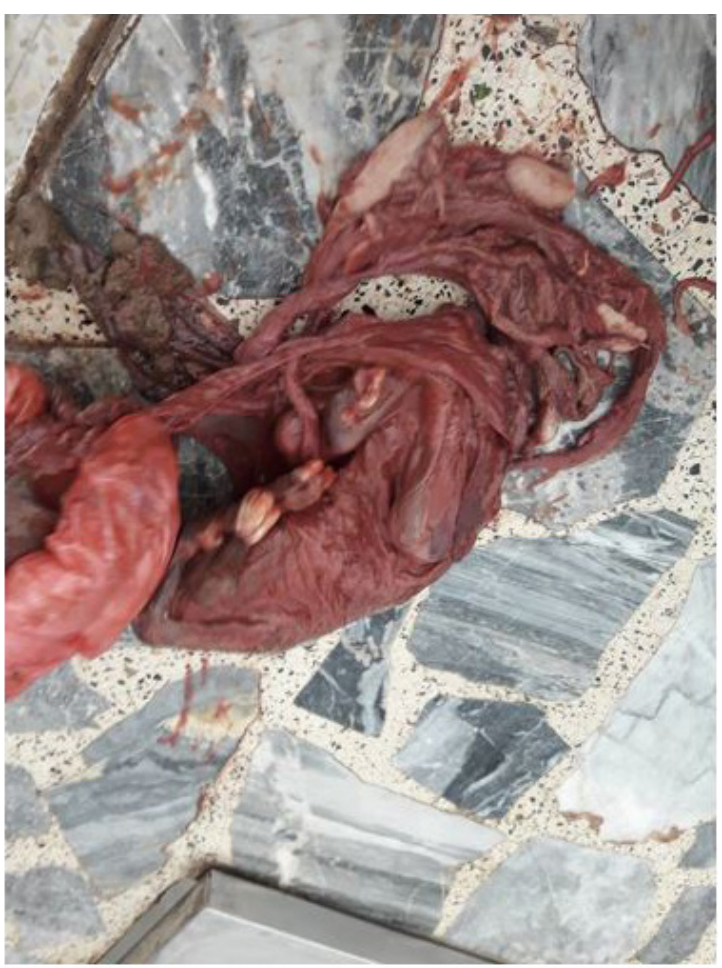

Figure 10. Shows the remnant mummified fetus.

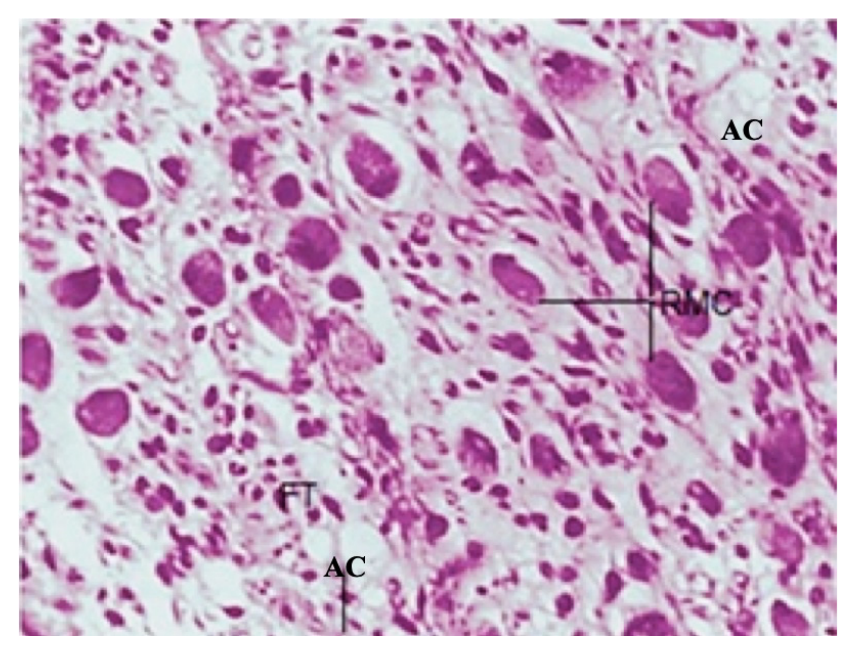

Figure 11. Shows the histopathological features of the skeletal muscle in the lamb with arthrogryposis and hydroencephaly. RMC: Rounding of the muscle cells, AC: Adipose cells, FT: and Fibrous tissue. H \& E stain. (X400). 


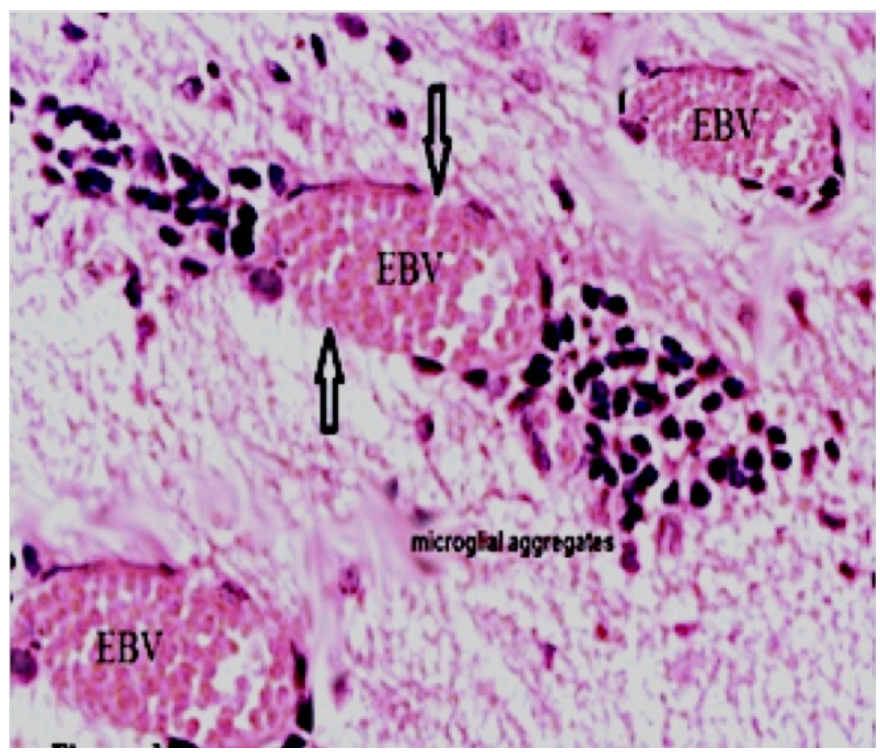

Figure 12. Shows the histopathological features of the cerebrum sections with microglial aggregates near a blood vessel (H\&E X400). EBV: Engorged blood vessel.

in brain and spinal cord sections. The sub-ependymal and deeper parts of the cerebrum revealed a cluster of glial cells, mostly microglia that were closer to the blood vessels (Figure 12).

\section{Discussion}

Akabane virus infection can lead to difficult delivery (lambing, calving and kidding). Death of both offspring and mother occurs because the deformed legs cannot get into the correct position for simple delivery. Akabane virus is in-utero teratogenic virus transmitted by different insect vectors, primarily midges, mosquitoes of the Aedes spp and Culex spp., and some species of tick (Merck Sharp \& Dohme Corp, 2019). The virus has a relatively narrow host distribution and infects ruminant (bovine, ovine, caprine) fetuses and causes congenital arthrogryposis, hydranencephaly, less frequently congenital polio encephalomyelitis, and rarely, acute encephalitis in both young calves and adult cattle (Walton, 1992).

The congenital abnormalities and arthrogryposis described in lambs in this study mimic a condition in cattle, sheep, and goats caused by Akabane virus disease that was reported previously by other researchers in natural and experimental infection (Konno \& Nakagawa, 1982; Konno et al., 1982; Parsonson et al., 1981; Stram et al., 2004). The clinical investigations in the present study indicated that the lambs had multiple body deformities. Moreover, varied mild to severe appendicular and axial skeleton deformities were found in all lambs. These deformities were arthrogryposis in all joints; immobility of multiple joints and fixed flexion accompanied with kyphosis; lordosis and abnormal head posture; a visible reduction of the brain size (microcephaly) and different degrees of hydrocephalus, and pale and firm muscle mass in most lambs.. The histopathological changes of the affected lambs seen in the nervous system (brain and spinal cord) and muscles included neuronal degeneration and muscular dystrophy. These lesions occurred due to the direct cytopathic effect of the virus on the developing neurons. These findings are compatible with those reported previously (Konno et al., 1982; Parsonson et al., 1981; Parsonson et al., 1977; Parsonson et al., 1983). In ovine, the lambs get infections trans placentally with the Akabane virus from 30-36 days of gestation and cause a severe infection of the fetus. However, the later gestation infection does not lead to significant disease in the fetus. In this study, the expectation of other teratogenic viruses, such as Rift Valley fever or Wesselsbron disease were not possible because of absence of a clinical finding that might be seen on the ewes like any catarrh of the buccal mucosa and coronitis. Meanwhile, other teratogenesis causes in ewes are associated with clinical findings like Rift Valley Fever and Bovine viral diarrhea.

The expectation of teratogenic plants was also excluded according to the presence of inflammatory processing that are absent in the case of teratogenic plants. Moreover, toxic plants or mineral imbalances were not deal in this congenital anomalies according to owner history and results of toxic plant investigators.

In the early gestation, the cells of subependymal matrix zone of the developing cerebral cortex and the myotubules of fetal muscles are infected with Akabane virus during the period of susceptibility. This results in a series of inflammatory processing due to necrosis of the embryonic cell and causes in the congenital disabilities. However, in the late gestation, the fetal host's cell is resistant to infection, and the fetus may clear the virus; thus, the diagnosis in lambs at term can only be made by detecting antibodies to Akabane virus in pre-colostral serum samples.

Akabane virus infection is distributed in Middle Eastern countries such as Cyprus, Iran (Ahi et al., 2015), Israel (Stram et al., 2004), Saudi Arabia (Abu Elzein et al., 1998), Jordan, Syrian Arab Republic and Turkey (Taylor \& Mellor, 1994). Geographically, Iraq is bordered by a vast area of these endemic countries such as Iran, Jordan, Saudi Arabia, Syrian Arab Republic, and Turkey. Since the last armed conflict in the area and devastating ISIS actions against humanity and nature that accompanied open Iraqi borders, it is possible that the disease was introduced into the country by the uncontrolled movements of infected 
animals. The situation was worsened by the presence of the arthropod vector such as Culicoides SPP biting midges. All these factors could encouraged the circulating the Akabane virus disease in Iraq. The affected lambs included in the present study reported from October 2017 to May 2018. Keeping in mind that the gestation period in sheep is five months, the ewes had most likely been infected during May and October 2017, the spring and autumn breeding times, respectively. This timeframe well coincided with the maximum abundance of Culicoides SPP midges in summer between May and October in Iraq. The authors recommend doing further future studies using serological tests, as well as virus isolation, to understand the epidemiological situation of this outbreak of congenital abnormalities and arthrogryposis in newly born lambs in Al-Muthanna province, Iraq. Suspect Akabane virus infection but also other causes of hydrocephalus or cerebellar malformation such as Schmallenberg virus, bluetongue virus and border disease virus have to be investigated. Consequently, considering the situation of the local weather conditions, the authorities should take prevention and control measurements to stop growth of insect vectors. In addition, accurate records of all affected lambs should be counted to determine the percentage of the disease in the total population of sheep in this province.

\section{Conflict of Interest}

There is no conflict of interest from any third party to publish this study.

\section{Ethics Statement}

No ethical issues may arise after the publication of this manuscript.

\section{Acknowledgements}

The authors would like to thank the staff of Al Muthanna veterinary hospital for help in providing data and samples.

\section{References}

Abu Elzein EME, Al-Afaleq AI, Mellor PS, El-Bashir AM, Hassanein MM. Study of Akabane infection in Saudi Arabia by the use if the sentinel ruminants. J Comp Pathol. 1998;119(4):473-8. http://dx.doi.org/10.1016/S00219975(98)80041-8. PMid:9839208.

Ahi MR, Pourmahdi-Borujeni M, Haji-Hajikolaei MR, Seifi-Abad-Shapouri MR. A serological survey on antibodies against akabane virus in sheep in Southwest of Iran. Indian J Virol. 2015;9(2):20-5.

Al-Salihi KA, Sahab A, Lifta A, Habib L. Epidemiological study of clinical and subclinical mastitis in she- camel in Samawah desert/Al-Muthanna governorate. Mirror of Research in Veterinary Sciences and Animals. 2017;6(2):1124. http://dx.doi.org/10.22428/mrvsa.

Al-Salihi KA. An insight into veterinary education in Iraq. Vet Rec. 2012;171(13):316-7. http://dx.doi.org/10.1136/ vr.e5145. PMid:23023493.

Bak UB, Lim CH, Cheong CK, Hwang WS, Cho MR. Outbreaks of Akabane virus disease of cattle in Korea. Korean J Vet Res. 1980;20:65-78.

Cybinski DH, St George TD, Paull NI. Antibodies to Akabane virus in Australia'. Aust Vet J. 1978;54(1):1-3. http://dx.doi. org/10.1111/j.1751-0813.1978.tb00256.x. PMid:655964.
Jun Q, Qingling M, Zaichao Z, Kuojun C, Jingsheng Z, Minxing M, Chuangfu C. A serological survey of Akabane virus infection in cattle and sheep in Northwest China. Trop Anim Health Prod. 2012;44(8):1817-20. http://dx.doi. org/10.1007/s11250-012-0168-3. PMid:22581316.

Konno S, Moriwaki M, Nakagawa M. Akabane disease in cattle: congenital abnormalities caused by viral infection. Spontaneous disease. Vet Pathol. 1982;19(3):246-66.

Konno S, Nakagawa M. Akabane disease in cattle: congenital abnormalities caused by viral infection. Experimental disease. Vet Pathol. 1982;19(3):267-79. http://dx.doi. org/10.1177/030098588201900305. PMid:7200279.

Kono R, Hirata M, Kaji M, Goto Y, Ikeda S, Yanase T, Kato T, Tanaka S, Tsutsui T, Imada T, Yamakawa M. Bovine epizootic encephalomyelitis caused by Akabane virus in southern Japan. BMC Vet Res. 2008;4(1):20. http://dx.doi. org/10.1186/1746-6148-4-20. PMid:18554406.

Lee H, Jeong H, Park S, Yang M-S, Kim J, Bae J, Kwon Y, Kim M-S, Oem J-K, Lee M-H, Lim C-W, Kim B. Experimental infection of cows with newly isolated Akabane virus strain (AKAV-7) causing encephalomyelitis. Vet Res (Faisalabad). 2016;47(1):62. http://dx.doi.org/10.1186/s13567-016-03496. PMid:27287214. 
Liao YK, Lu YS, Goto Y, Inaba Y. The isolation of Akabane virus (Iriki strain) from calves in Taiwan. J Basic Microbiol. 1996;36(1):33-9. http://dx.doi.org/10.1002/jobm.3620360108. PMid:8819843.

Merck Sharp \& Dohme Corp [Internet]. Akabane virus infection. Kenilworth: Merck Sharp \& Dohme Corp; 2019 [cited 2019 Feb 17]. Available from: https://www. merckvetmanual.com/generalized-conditions/congenitaland-inherited-anomalies/akabane-virus-infection

Metselaar D, Robin Y. Akabane virus isolated in Kenya. Vet Rec. 1976;99(5):86. http://dx.doi.org/10.1136/vr.99.5.86-a. PMid:982784.

Oya A, Okuno T, Ogata T, Kobayashii, Matsuyama T. Akabane, a new arbovirus isolated in Japan. Jpn J Med Sci Biol. 1961;14(3):101-8. http://dx.doi.org/10.7883/ yoken1952.14.101. PMid:14482934.

Parsonson IM, Della-Porta AJ, O'Halloran ML, Snowdon WA, Fahey KJ, Standfast HA. Akabane virus infection in the pregnant ewe.1. Growth of virus in the foetus and the development of the foetal immune response. Vet Microbiol. 1981;6(3):197-207. http://dx.doi.org/10.1016/03781135(81)90013-4.

Parsonson IM, Della-Porta AJ, Snowdon WA. Congenital abnormalities in newborn lambs after infection of pregnant sheep with akabane virus. Infect Immun. 1977;15(1):25462. PMid:832900.
Parsonson IM, Della-Porta AJ, Snowdon WA. Congenital abnormalities in foetal lambs after inoculation of pregnant ewes with Akabane virus. Aust Vet J. 1983;60:137-40.

Stram Y, Brenner J, Braverman Y, Banet-Noach C, Kuznetzova L, Ginni M. Akabane virus in Israel: a new virus lineage. Virus Res. 2004;104(1):93-7. http://dx.doi.org/10.1016/j. virusres.2004.03.004. PMid:15177897.

Taylor WP, Mellor PS. The distribution of Akabane virus in the Middle East. Epidemiol Infect. 1994;113(1):175-85. http:// dx.doi.org/10.1017/S0950268800051591. PMid:8062874.

Veterinary Directorate Livestock. [Internet]. Census of veterinary directorate. Republic of Iraq: Ministry of Agriculture; 2008 [cited 2019 Feb 17]. Available from: http:// www.vetsc.gov.iq/upload/upfile/ar/1survy\%202008.pdf

Walton TE. Veterinary diagnostic virology: a practitioners guide. Missouri: Mosby Inc.; 1992.

Financial Support: No fund has been received from any authorities to support this work (self-funded by the authors).

Authors Contributions: All authors contribute equally in the preparation, development and publication of this manuscript. 